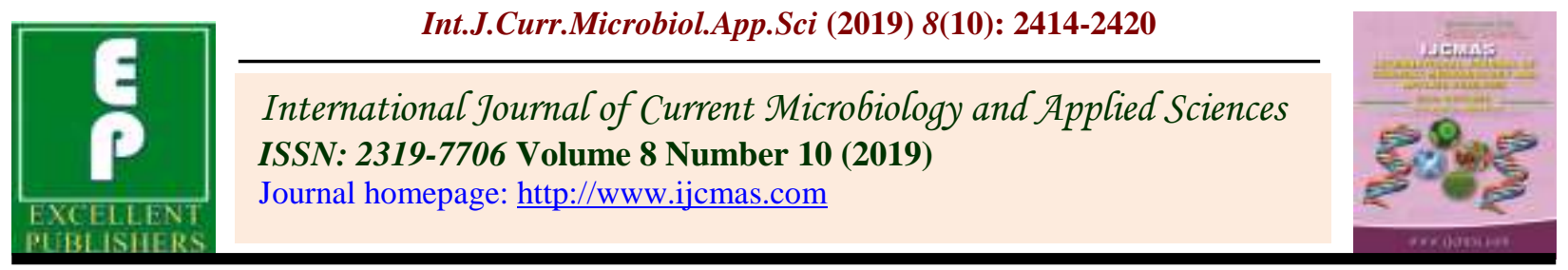

Original Research Article

https://doi.org/10.20546/ijcmas.2019.810.280

\title{
Morphological and Bio-chemical Characterization of Bael (Aegle marmelos Correa.) in West Garo Hills, Meghalaya, India
}

\author{
J. P. Lyngdoh Pale*, Sanjay Chetri, C. P. Suresh, Y. S. Singh, \\ A. Chaurasiya and A. Barman
}

Department of Horticulture, North-Eastern Hill University (N.E.H.U.), Chasingre, West Garo Hills 794002, Meghalaya, India

*Corresponding author

\section{A B S T R A C T}

\section{Keywords}

Morphological,

Biochemical,

Organoleptic, Aegle marmelos,

Variability

\section{Article Info}

Accepted:

17 September 2019

Available Online:

10 October 2019
The present study entitled, "Morphological and Biochemical Characterization of Bael (Aegle marmelos Correa.) in West Garo Hills, Meghalaya" was carried out in Garo Hills of Meghalaya, India during 2017-2018 at Department of Horticulture, North Eastern Hill University, Chasingre, Tura campus, in West Garo Hills Districts, Meghalaya. Thirty different accessions of bael fruits were collected from different locations of West Garo Hills and the analysis of variance was carried out in a Completely Randomized Design with three replications. The result revealed that significant variation in respect of their morphological and biochemical characters. Based on the quantitative, biochemical and organoleptic characters, accessions collected from location-3 i.e., Cherangre, location-5 i.e., Sampalgre and location-6 i.e., Babupara were found to be the best and promising accessions.

\section{Introduction}

Bael (Aegle marmelos Correa.) also known as Bengal quince, Bilva, Bilpatre, Maredu, Shul, Vilvam, Shaiphal, etc., belongs to the family Rutaceae. In Garo language, bael is called as 'Selfree'. It is a subtropical plant which can grow up to an altitude of $1200 \mathrm{~m}$ from the sea level. The generic name 'Aegle' is of Greek origin and the species 'marmelos' is of
Portuguese origin. Aegle belong to one of the three monotypic genera of orange sub family Aurantioideae, tribe Clauseneae and sub-tribe Balsamocitrinea (Nair and Barche, 2016). The chromosome number $2 \mathrm{n}=36$. Bael can adapt a wide range of habitat and can be cultivated worldwide. It is native to India and has its origin from Eastern Ghats and Central India. In India, it is distributed throughout the country but concentrated area under bael is in 
Eastern parts of the Gangetic plains and nearby areas particularly in Uttar Pradesh, Bihar, West Bengal and Orissa. It is also available in wild form in sub-Himalayan tract from Rajasthan to West Bengal, Central and Southern India.

The bael fruit has been known in India from prehistoric writings dating back to 800 B.C. The leaves of the tree are traditionally used as sacred offerings to "Lord Shiva," according to Hindu customs. It is also called Shivadurme, the tree of Shiva. According to Hindu mythology, the tree is another form of Lord Kailashnath. It is also sacred to Parvati and is the Vilvarupra, one of the Patricas, or nine forms of Goddess Kali (Sharma et al., 2007).

Bael is a nutritious and medicinal fruit, which is most suitable for water scarce areas of the country. Every part of the bael tree whether stem, bark, root, leaves or fruit at different maturity stages is utilized for various purposes. It is used in the preparation of several Ayurvedic medicines since ancient times (Rai and Dwivedi, 1992). Marmelocin is probably the therapeutically active factor of bael fruit and is known as the 'panaceae' of the stomach ailments.

\section{Materials and Methods}

The present study entitled, "Morphological and Biochemical Characterization of Bael (Aegle marmelos Correa.) in West Garo Hills, Meghalaya" was carried out in Garo Hills of Meghalaya, India during 2017-2018 at the Department of Horticulture, North Eastern Hill University, Chasingre, Tura campus, in West Garo Hills Districts, Meghalaya situated approximately between the latitudes of $90^{\circ}$ $30^{\prime}$ and $89^{\circ} 40^{\prime} \mathrm{E}$, and the longitudes of $26^{\circ}$ and $25^{\circ} 20^{\prime} \mathrm{N}$. Thirty different accessions of bael fruits were collected from different locations in West Garo Hills viz., location-1 i.e., Rongram, location-2 i.e., Rongkhon, location-3 i.e., Cherangre, location-4 i.e., Reserve Gittim, location-5 i.e., Sampalgre, location-6 i.e., Babupara, loation-7 i.e., Hawakhana, location-8 i.e., Sangsangre, location-9 i.e., Dobasipara and location-10 i.e., Sunny Hills, and the analysis of variance was carried out in a Completely Randomized Design with three replications. The trees and fruits characters collected from all the locations were measured for their morphological characters. The bio-chemical characters of the fruits also was analysed using the standard methods (AOAC 1990). The organoleptic quality of the fruit pulp of all the accessions collected from different locations were distributed to a team of panellist for overall acceptability that actually included the point like colour, aroma/flavour, taste and acridity on a 5.00 Point Hedonic Scale (Amerine et al., 1965). The accessions receiving high score in pulp colour, pulp taste, pulp aroma, and low score in pulp acridity was considered acceptable.

\section{Statistical analysis}

The test for significance was done by following the method described by Panse and Sukhatme (1967), while the method described by Mahalanobis (1932) was followed for Completely Randomized Block Design and Factorial Completely Randomized Design. The analysis of variance (ANOVA) of the data was carried out by the techniques as suggested by Ragharamula et al., (1983). Correlation analysis was done by using SPSS Software Version 16.0.

\section{Results and Discussion}

\section{Morphological characters}

The variations observed among the accessions collected were recorded and presented in Table 1. The highest tree height was recorded from location-6 i.e., Babupara (8.67 m), while 
the lowest tree height from location-4 i.e., Reserve Gittim (5.67 m). The maximum trunk girth was recorded from location-5 i.e., Sampalgre $(132.03 \mathrm{~cm})$, while the lowest trunk girth was recorded from location-1 i.e., Rongram $(66.13 \mathrm{~cm})$. The maximum tree spread in term of North-South direction was recorded from location-8 i.e., Sangsangre $(7.62 \mathrm{~m})$ and the maximum tree spread in term of East-West direction was recorded from location-5 i.e., Sampalgre $(6.81 \mathrm{~m})$, the minimum tree spread in term of both NorthSouth and East-West direction was recorded from location-3 i.e., Cherangre $(4.83 \mathrm{~m})$ and (3.57 m).

Similar finding were found by Patil et al., (2017); Simla et al., (2017), Kumar et al., (2014) and Goswami et al., (2011) while working on the morphological characters of the fruit crop, they found that there was a wide variation in the tree height, width, tree spread and number of fruits per tree.

\section{Quantitative characters of the fruits}

Significant variations were recorded from among the accessions collected from different locations and have been presented in Table 2 .

Maximum fruit length was recorded from location-5 i.e., Sampalgre $(16.31 \mathrm{~cm})$, while the lowest fruit length was noted in location-3 i.e., Cherangre $(11.50 \mathrm{~cm})$. The accessions collected from location-5 i.e., Sampalgre recorded significantly maximum fruit width $(16.94 \mathrm{~cm})$, significantly highest fruit weight $(0.57 \mathrm{~kg})$, significantly maximum pulp weight (62.11g) and maximum number of seeds per fruit (52.71). Location-3 i.e., Cherangre recorded the minimum fruit length $(11.50 \mathrm{~cm})$, significantly minimum fruit width $(9.34 \mathrm{~cm})$, significantly lowest fruit weight $(0.15 \mathrm{~kg})$, minimum fruit skull thickness $(2.19 \mathrm{~mm})$, significantly lowest pulp weight (31.66g), significantly minimum numbers of fruits per tree (14.33) and significantly minimum number of seeds per fruit (31.57). Such Similar findings with respect in this parameter were reported by Singh et al., (2000); Lal (2002); Shrivastava and Singh (2004); Saroj et al., (2008); Pandey et al., (2008); Mitra et al., (2010); Pandey et al., (2013); Kumar and Nath (2015); Uddin et al., (2016) and Nagar et al., (2017).

\section{Bio-chemical characters}

The variations observed among the accessions collected have been presented in Table 3 . Significantly highest TSS $\left(35.47{ }^{0}\right.$ Brix) was recorded from location-3 i.e., Cherangre, while the lowest TSS $\left(24.80^{\circ}\right.$ Brix $)$ from location-1 i.e., Rongram. The accessions collected from location-3 i.e., Cherangre recorded minimum titrable acidity $(0.23 \%)$ and highest total sugars (25.38 The highest reducing sugar was recorded from location-10 i.e., Sunny Hills (8.84 \%), while the lowest was recorded from location-9 i.e., Dobasipara (4.69\%).

Lowest total sugars and non reducing sugars was recorded from location-1 i.e., Rongram $(14.34 \%)$ and $(6.67 \%)$. The highest titrable acidity was recorded from location-7 i.e., Hawakhana $(0.45 \%)$. Earlier workers also reported similar variation in these characters Nagar et al., (2017); Kaur and Kalia (2017); Uddin et al., (2016); Kumar and Nath (2015); Singh et al., (2014a); Singh et al.,(2014); Ram and Singh (2003) and Bhadre and Sen (1997).

\section{Organoleptic characters}

Pulp characters from the accessions collected from different locations were recorded and presented in Table 4. The highest pulp taste was recorded from accessions from location-6 i.e., Babupara (3.34), while the lowest pulp colour was recorded from location-3 i.e., Cherangre (2.90). 
Table.1 Morphological characters of the trees

\begin{tabular}{|c|c|c|c|c|}
\hline \multirow[t]{2}{*}{ Location } & \multirow[t]{2}{*}{ Tree height(m) } & \multirow{2}{*}{$\begin{array}{c}\text { Truck } \\
\operatorname{girth}(\mathrm{cm})\end{array}$} & \multicolumn{2}{|c|}{ Tree spread (m) } \\
\hline & & & North- South & East-West \\
\hline $\mathrm{L}_{1}-\mathbf{R r}$ & 6.53 & 66.13 & 6.45 & 6.03 \\
\hline $\mathbf{L}_{2}-\mathbf{R k}$ & 8.57 & 117.10 & 5.34 & 5.95 \\
\hline $\mathrm{L}_{3}-\mathrm{Cg}$ & 7.13 & 84.66 & 4.83 & 3.57 \\
\hline $\mathrm{L}_{4}-\mathbf{R g}$ & 5.67 & 71.78 & 5.17 & 5.03 \\
\hline $\mathbf{L}_{5}-\mathbf{S p}$ & 7.40 & 132.03 & 7.20 & 6.81 \\
\hline $\mathrm{L}_{6}-\mathrm{Bp}$ & 8.67 & 78.93 & 6.83 & 6.71 \\
\hline $\mathbf{L}_{7}-\mathbf{H k}$ & 7.47 & 77.40 & 5.73 & 6.37 \\
\hline $\mathrm{L}_{8}-\mathrm{Sg}$ & 6.47 & 84.34 & 7.62 & 6.50 \\
\hline$L_{9}-\mathrm{Dp}$ & 6.30 & 75.53 & 5.36 & 5.56 \\
\hline $\mathbf{L}_{10}-\mathrm{Sh}$ & 6.43 & 79.35 & 6.12 & 6.47 \\
\hline S.Ed & 0.68 & 7.01 & 0.54 & 0.53 \\
\hline CD $(5 \%)$ & 1.433 & 14.72 & 1.13 & 1.12 \\
\hline CV\% & 11.82 & 9.90 & 10.88 & 11.03 \\
\hline
\end{tabular}

Table.2 Quantitative characters of the fruits

\begin{tabular}{|c|c|c|c|c|c|c|c|c|}
\hline Location & $\begin{array}{l}\text { Fruit } \\
\text { length } \\
(\mathrm{cm})\end{array}$ & $\begin{array}{c}\text { Fruit } \\
\text { width } \\
\text { (cm) }\end{array}$ & $\begin{array}{c}\text { Fruit } \\
\text { weight } \\
\text { (kg) }\end{array}$ & $\begin{array}{l}\text { Fruit skull } \\
\text { thickness } \\
\text { (mm) }\end{array}$ & $\begin{array}{c}\text { Pulp } \\
\text { weight } \\
\text { (g) }\end{array}$ & $\begin{array}{l}\text { No. of } \\
\text { seeds/ } \\
\text { Fruit }\end{array}$ & $\begin{array}{c}\text { No. of } \\
\text { fruits/tree }\end{array}$ & $\begin{array}{c}\text { Length } \\
\text { :Width } \\
\text { ratio }\end{array}$ \\
\hline $\mathrm{L}_{1}-\mathbf{R r}$ & 13.50 & 13.33 & 0.34 & 2.59 & 40.68 & 36.67 & 36.67 & 1.02 \\
\hline $\mathbf{L}_{2}-\mathbf{R k}$ & 12.79 & 11.04 & 0.17 & 2.58 & 37.27 & 43.75 & 22.13 & 1.04 \\
\hline $\mathrm{L}_{3}-\mathrm{Cg}$ & 11.50 & 9.34 & 0.15 & 2.19 & 31.66 & 31.57 & 14.33 & 1.18 \\
\hline $\mathrm{L}_{4}-\mathbf{R g}$ & 16.21 & 13.00 & 0.32 & 2.65 & 42.05 & 43.07 & 21.73 & 1.24 \\
\hline $\mathbf{L}_{5}-\mathrm{Sp}$ & 16.31 & 16.94 & 0.57 & 2.76 & 62.11 & 52.71 & 26.70 & 0.98 \\
\hline $\mathrm{L}_{6}-\mathrm{Bp}$ & 14.42 & 13.60 & 0.23 & 2.35 & 38.70 & 49.73 & 36.30 & 1.20 \\
\hline $\mathrm{L}_{7}-\mathrm{Hk}$ & 12.23 & 12.67 & 0.24 & 2.34 & 37.12 & 45.10 & 25.77 & 0.87 \\
\hline $\mathbf{L}_{8}-\mathrm{Sg}$ & 12.62 & 11.62 & 0.22 & 3.64 & 34.67 & 35.98 & 28.67 & 1.12 \\
\hline $\mathrm{L}_{9}$-Dp & 13.76 & 12.25 & 0.26 & 2.61 & 41.01 & 42.43 & 31.90 & 1.08 \\
\hline $\mathbf{L}_{10}-\mathrm{Sh}$ & 14.86 & 14.51 & 0.28 & 2.67 & 45.75 & 47.39 & 24.43 & 1.14 \\
\hline S.Ed & 0.91 & 0.66 & 0.024 & 0.20 & 2.82 & 4.19 & 3.02 & - \\
\hline CD $(5 \%)$ & 1.92 & 1.38 & 0.10 & 0.42 & 5.92 & 8.79 & 6.35 & - \\
\hline CV\% & 8.095 & 6.27 & 10.74 & 9.26 & 8.40 & 11.97 & 13.78 & - \\
\hline
\end{tabular}


Table.3 Biochemical characters of the fruits

\begin{tabular}{|c|c|c|c|c|c|c|c|}
\hline Location & $\begin{array}{c}\text { TSS } \\
\left({ }^{0} \mathrm{Brix}\right)\end{array}$ & $\begin{array}{c}\text { Titrable } \\
\text { acidity } \\
(\%)\end{array}$ & $\begin{array}{l}\text { Total } \\
\text { sugar }\end{array}$ & $\begin{array}{l}\text { Reducing } \\
\text { sugar }\end{array}$ & $\begin{array}{l}\text { Non- } \\
\text { reducing } \\
\text { sugar }\end{array}$ & $\begin{array}{l}\text { TSS:Acid } \\
\text { ratio }\end{array}$ & $\begin{array}{c}\text { Sugar: } \\
\text { Acid ratio }\end{array}$ \\
\hline $\mathbf{L}_{1}-\mathbf{R r}$ & 24.80 & 0.38 & 14.34 & 7.31 & 6.67 & 60.11 & 37.59 \\
\hline $\mathbf{L}_{2}-\mathbf{R k}$ & 29.07 & 0.36 & 21.80 & 7.26 & 13.82 & 78.42 & 62.18 \\
\hline $\mathrm{L}_{3}-\mathrm{Cg}$ & 35.47 & 0.23 & 25.38 & 8.84 & 15.71 & 108.21 & 114.43 \\
\hline $\mathrm{L}_{4}-\mathrm{Rg}$ & 27.33 & 0.34 & 18.16 & 6.16 & 11.40 & 83.53 & 54.57 \\
\hline $\mathrm{L}_{5}-\mathrm{Sp}$ & 32.33 & 0.26 & 16.74 & 8.67 & 7.67 & 76.27 & 39.32 \\
\hline $\mathbf{L}_{6}-\mathbf{B p}$ & 25.20 & 0.43 & 15.48 & 8.17 & 6.94 & 80.95 & 59.43 \\
\hline $\mathbf{L}_{7}-\mathbf{H k}$ & 25.60 & 0.45 & 17.29 & 8.38 & 8.47 & 57.11 & 38.63 \\
\hline $\mathrm{L}_{8}=\mathrm{Sg}$ & 29.73 & 0.35 & 22.93 & 6.80 & 15.33 & 79.40 & 64.80 \\
\hline $\mathbf{L}_{9}-\mathrm{Dp}$ & 25.27 & 0.37 & 23.26 & 4.69 & 17.64 & 69.80 & 63.32 \\
\hline $\mathbf{L}_{10}-\mathrm{Sh}$ & 27.40 & 0.33 & 19.61 & 7.86 & 10.23 & 85.49 & 60.93 \\
\hline S.Ed & 2.26 & 0.04 & 1.53 & 0.79 & 1.15 & - & - \\
\hline $\operatorname{CD}(5 \%)$ & 4.71 & 0.08 & 3.20 & 1.65 & 2.40 & - & - \\
\hline CV\% & 9.81 & 13.74 & 9.64 & 13.01 & 12.26 & - & - \\
\hline
\end{tabular}

Table.4 Organoleptic characters of the fruit pulp

\begin{tabular}{|c|c|c|c|c|}
\hline Location & Pulp colour & $\begin{array}{c}\text { Pulp } \\
\text { aroma/flavor }\end{array}$ & Pulp taste & Pulp acridity \\
\hline $\mathbf{L}_{\mathbf{1}}-\mathbf{R r}$ & 2.94 & 2.98 & 3.50 & 1.35 \\
\hline $\mathbf{L}_{\mathbf{2}}-\mathbf{R k}$ & 3.08 & 3.04 & 3.82 & 1.25 \\
\hline $\mathbf{L}_{\mathbf{3}}-\mathbf{C g}$ & 2.90 & 3.1 & 3.89 & 1.03 \\
\hline $\mathbf{L}_{\mathbf{4}}-\mathbf{R g}$ & 3.16 & 3.14 & 2.51 & 1.28 \\
\hline $\mathbf{L}_{\mathbf{5}}-\mathbf{S p}$ & 3.06 & 2.99 & 3.14 & 1.33 \\
\hline $\mathbf{L}_{\mathbf{6}}-\mathbf{B p}$ & 3.34 & 3.61 & 3.92 & 0.96 \\
\hline $\mathbf{L}_{\mathbf{7}}-\mathbf{H k}$ & 2.95 & 3.07 & 2.22 & 1.06 \\
\hline $\mathbf{L}_{\mathbf{8}}-\mathbf{S g}$ & 2.91 & 3.12 & 2.76 & 1.34 \\
\hline $\mathbf{L}_{\mathbf{9}}-\mathbf{D} \mathbf{P}$ & 3.04 & 3.49 & 3.85 & 0.99 \\
\hline $\mathbf{L}_{\mathbf{1 0}}-\mathbf{S h}$ & 3.24 & 3.41 & 2.20 & 1.31 \\
\hline $\mathbf{S . E d}$ & $\mathbf{0 . 1 1}$ & $\mathbf{0 . 1 7}$ & $\mathbf{0 . 0 6}$ & $\mathbf{0 . 1 2}$ \\
\hline $\mathbf{C D}(\mathbf{5 \%})$ & $\mathbf{0 . 2 2}$ & $\mathbf{0 . 3 4}$ & $\mathbf{0 . 1 3}$ & $\mathbf{0 . 0 3}$ \\
\hline CV\% & $\mathbf{5 . 6 8}$ & $\mathbf{8 . 3 5}$ & $\mathbf{3 . 1 1}$ & $\mathbf{1 . 9 8}$ \\
\hline
\end{tabular}

The accessions collected from location-6 i.e., Babupara showed highest pulp taste (3.92), highest pulp flavour (3.61) and lowest pulp acridity (0.96).

The different accessions of bael fruits collected from different locations of West
Garo Hill varied significantly with respect to plant morphology, bearing habit, fruiting, fruit growth and morpho-physico-chemical properties of fruits. Based on the results obtained from the present investigation, it can be concluded that all the accessions of bael exhibited noticeable variation in their 
morphological and bio-chemical characteristics.

Based on the quantitative characters of the fruit, it was recorded that the best accessions was recorded from location-5 i.e., Sampalgre with fruit length $(16.31 \mathrm{~cm})$, fruit width $(16.94$ $\mathrm{cm})$, fruit weight $(0.57 \mathrm{~kg})$, pulp weight $(62.11$ g) and number of seeds per fruit (52.71).

With respect to the fruit quality, the best accessions were recorded from location-3 i.e., Cherangre with a $\operatorname{TSS}\left(35.47^{\circ}\right.$ Brix $)$, titrable acidity $(0.23 \%)$, total sugars $(25.38 \%)$, reducing sugars (8.84), TSS: acid ratio (108.21) and Sugar: acid ratio (114.43).

Based on the organoleptic quality viz., pulp colour (3.34), pulp flavour/aroma (3.61), pulp taste (3.92) and pulp acridity (0.96) was considered acceptable from location- 6 i.e., Babupara. The correlation between the quantitative and biochemical characters among bael accessions were observed be have a significant positive and negative between the accessions.

Therefore, the accessions collected from these three locations namely, location-3 i.e., Cherangre, location-5 i.e., Sampalgre and location- 6 i.e., Babupara could be used for further evaluation.

\section{References}

Amerine, M.A., Pangborn, R.M. and Roessler, E.B. (1965). Principle of Survey Evaluation of Food., Academic Press Inc., New York.

A.O.A.C. (1990). Official methods of analysis. Association of Official Analytical Chemists. 15 ed. Arlington.

Baseline survey of minority districts (West Garo Hills). Omeo Kumar Das Institute of Social change and Development: Guwahati.
Bhadra, S. and Sen, S.K. (1997). Studies on the developmental physiology of bael (Aegle marmelos Correa.) fruit variety, Kalyani Selection-I. Prog. Hort., Vol. 29 (3-4): 135-137.

Goswami, C., Hossain, M.A., Kader, H.A. and Islam, R. (2018). Assessment of physicochemical properties of jackfruits' (Artocarpus heterophyllus Lama) pulps. Journal of Horticulture, Forestry and Biotechnology., Vol. 15(3): 6-11.

Gupta, N.K., Misra, K.K., Singh, O. And Ratna, K. (2016). Correlation study in bael Aegle marmelos. Correa). Progressive Horticulture., Vol: 48(1): 116-118

Islam, M.S., Ibrahim, M.S., M. Hossain, M.M. and Kamal, A.M. (2012).Studies on morphological and fruit characters of bael. International Journal of Sustainable Agricultural Technology., Vol. 8(7): 24-27.

Kaur, A. and Kalia, M. (2017). Physicochemical analysis of bael (Aegle marmelos) fruit pulp, seed and pericarp. ChemSci Rev Lett., Vol. 6(22): 1213-1218.

Kaushik, R.A., Yamdagni, R. and Dhawan, S.S. (2000). Physico- chemical characteristics of bael (Aegle marmelos Correa.) fruit at green stage and ripe stage of maturity. Haryana Journal of Horticultural Sciences., Vol. 29(12):44-45.

Kumar, D. and Nath, V. (2015).Variability in Bael (Aegle marmelos Correa) Genotypes from Orissa. Indian J. Plant Genet. Resourc., Vol. 23(3): 303-305.

Kumar, D., Rajput, C.B.S. and Singh, S.P. (1996). Survey of some important bael (Agele marmelos Correa.) genotypes in Varanasi region. Recent Horticulture., Vol. 3(1): 49-51. 
Lal, G. (2002). Evaluation of bael (Aegle marmelos Correa) germplasm in semiarid

regions of Rajasthan. Current Agriculture., Vol. $26(1 / 2): 127-129$.

Mitra, S.K., Maity, C.S., Mani, D. and Ghosh, B (2010). Genetic resources of bael (Aegle marmelos Correa.) - a potential underutilized fruit. Acta Horticulturae., Vol. 86 (4): 49 - 51.

Nagar, S., Kumar, M., Kumatkar, R. B., Sharma, J.R. and Singh, S.(2017). Evaluation of bael (Aegle marmelos Corr.) germplasms for seed and qualitative characters under semi-arid conditions of Haryana. Int. J. Pure App. Biosci., Vol. 5 (3): 436-442.

Orwa, C., Mutua, A., Kindt, R., Jamnadass, R. and Anthony, S. (2009). Aegle marmelos Correa. Agroforestry Database., Vol. 4:4-5.

Pandey, D., Shukla, S.K. and Kumar, A. (2008). Variability in bael accessions from Bihar and Jharkhand. Indian Journal of Horticulture., Vol. 65 (2): $226-229$.

Ram, D. and Singh, I.S. (2003). Physicochemical studies of bael (Aegle marmelos Correa.) fruits. Progressive Horticulture., Vol. 35(2): 199-201.
Roy, S.A. and Singh, R.N. (1979).Bael fruit (Aegle marmelos)-a potential fruit for processing. Economic Botany., Vol. 33 (2):203-212.

Saroj, P.L., More, T.A. and Singh, U.V. (2008).Performance of bael (Aegle marmelos) cultivars under hot arid ecosystem of Rajasthan. Indian Journal of Agricultural Sciences., Vol. 78(12): 1071-1074.

Singh, A.K., Singh, S., Singh, R.S., Joshi, H.K. and Sharma, S.K. (2014). Characterization of bael (Aegle marmelos) varieties under rainfed hot semi-arid environment of western India. Journal of Agricultural Sciences., Vol. 84(10):1236-1242.

Srivastava, K.K. and Singh, H.K. (2004).Physico-chemical quality of bael (Aegle marmelos Correa.) cultivars. Agric.Sci. Digest., Vol. 24(1): 65-66.

Uddin, M.S., Islam, M.S., Alam, M.A. Hossain, M.M. (2016). Study on physico-morphological charateristics of 14 bael (Aegle marmelos Correa.) genotypes grown at Chapainawabganj, Bangladesh. International Journal of Minor Fruits, Medicinal and Aromatic Plants., Vol. 2(2): 29-33.

\section{How to cite this article:}

Lyngdoh Pale, J. P., Sanjay Chetri, C. P. Suresh, Y. S. Singh, A. Chaurasiya and Barman, A. 2019. Morphological and Bio-chemical Characterization of Bael (Aegle marmelos Correa.) in West Garo Hills, Meghalaya, India. Int.J.Curr.Microbiol.App.Sci. 8(10): 2414-2420. doi: https://doi.org/10.20546/ijcmas.2019.810.280 